\title{
Glucagon Deficiency Associated with Hypoglycaemia and the Absence of Islet Cell Antibodies in the Polyglandular Failure Syndrome Before the Onset of Insulin-Dependent Diabetes Mellitus: A Case Report
}

\author{
A.A. R.Starke ${ }^{1}$, I. Valverde ${ }^{2}$, G. F. Bottazzo ${ }^{3}$, M. Tsotsalas ${ }^{1}$ and H.Zimmermann ${ }^{1}$ \\ ${ }^{1}$ Department of Medicine E, University of Düsseldorf, Düsseldorf, FRG, ${ }^{2}$ Fundacion Jiminez Diaz, Universidad Autonoma de Madrid, \\ Madrid, Spain, and ${ }^{3}$ Department of Immunology, The Middlesex Hospital Medical School, London, UK
}

\begin{abstract}
Summary. The case of a female patient with fasting hypoglycaemia before the development of Type 1 (insulin-dependent) diabetes mellitus is reported. She presented with primary hypothyroidism, partial hypopituitarism, adrenal insufficiency and glucagon deficiency. Thyroid microsomal and gastric parietal cell antibodies were detected as well as HLA-B8, whereas islet cell antibodies were not demonstrable, even 2 years after the onset of diabetes. Plasma chromatography revealed true pancreatic glucagon (IRG ${ }^{3500}$ ) close to undetectable in basal samples with a questionable increase from 3 to $18 \mathrm{pg} / \mathrm{ml}$ during insulin-induced hypoglycaemia. After an overnight fast, moderate hyperaminoacidaemia was found
\end{abstract}

with elevations of alanine, glycine, serine, arginine and ornithine as seen in pancreatectomized patients. It is suggested that the deficient glucagon secretion in this patient might, at least in part, have been the cause of fasting hypoglycaemia and the failure of glucose recovery following insulin-induced hypoglycaemia. Possibly, the A cell deficiency was part of the polyglandular failure syndrome in this patient.

Key-words: Polyglandular failure syndrome, hypoglycaemia, glucose counter-regulation, diabetes mellitus, glucagon deficiency, glucagon and plasma amino acids.
The high prevalence of diabetes mellitus in patients with thyroid and adrenal insufficiency (Schmidt's syndrome) has been reported in detail [1-4]. The detection of autoantibodies and certain histocompatibility leucocyte antigens in these patients indicates that the polyglandular failure syndrome may be due to autoimmune processes [5-7]. Evidence of inappropriate glucagon secretion in patients with the polyglandular failure syndrome has hitherto not been reported. Vidnas et al. [8] reported the first case of isolated congenital glucagon deficiency causing severe neonatal hypoglycaemia. Earlier reports of glucagon deficiency were based upon histological evidence of reduced A cells and not verified by simultaneous glucagon measurements [9]. The fundamental role of glucagon in glucose recovery from insulin-induced hypoglycaemia has been assessed in studies with pharmacological inhibition of glucagon [10] but glucagon deficiency has not been verified by chromatography.

\section{Subject and Methods}

\section{Patient}

A 27-year-old female patient with fasting hypoglycaemia $(<2$ $\mathrm{mmol} / \mathrm{l}$ ) was referred to our metabolic ward in 1979 for suspected in- sulinoma. There was no family history of endocrinopathies. Before admission several episodes of hypoglycaemia occurred during food deprivation due to toothache. Besides a homogeneously enlarged thyroid gland, no clinical abnormalities were found. We had the opportunity to see the patient repeatedly over a period of 2.5 years.

Hormones were assayed with standard radioimmunological techniques using commercial kits. Plasma glucagon (IRG) was measured with the specific antibody $30 \mathrm{~K}$ as described previously [11]. Standard diagnostic tests for evaluating disorders of the endocrine system were used and were performed before any replacement therapy [12]. Tests were carried out using: ACTH $(0.25 \mathrm{mg}$ tetracosactid IV; Synacthen, Ciba-Geigy, Wehr/Baden, FRG); vasopressin (5 IU ornipressin IV/ $30 \mathrm{~min}$; POR 8 Sandoz, Nürnberg, FRG; TRH ( $400 \mu \mathrm{g}$ synthetic TRH'IV); and LH-RH (100 $\mu \mathrm{g}$ synthetic LH-RH' IV; Relefact, Hoechst, Frankfurt, FRG). Serum amino acids were assayed using a Biotronik analyzer (Biotronik, Frankfurt, FRG) [13]. HLA-typing was performed by standard microlymphotoxity testing. The technique of autoantibody determination has been described in detail [3]. Reference data of normal subjects were available for arginine-infusions $(n=20)$, insulin tolerance tests $(n=15)$ and glucagon chromatography $(n=18)$.

\section{Glucagon Chromatography [14]}

Plasma samples (2.4-3.0 ml) obtained before and after insulin and arginine administration were loaded on $40 \times 1 \mathrm{~cm}$ Biogel P30 columns (Biorad Laboratories, Richmond, California, USA). Variations in the values of total IRG in plasma samples and chromatography are due to the use of different batches of the $30 \mathrm{~K}$ antiserum reacting different- 


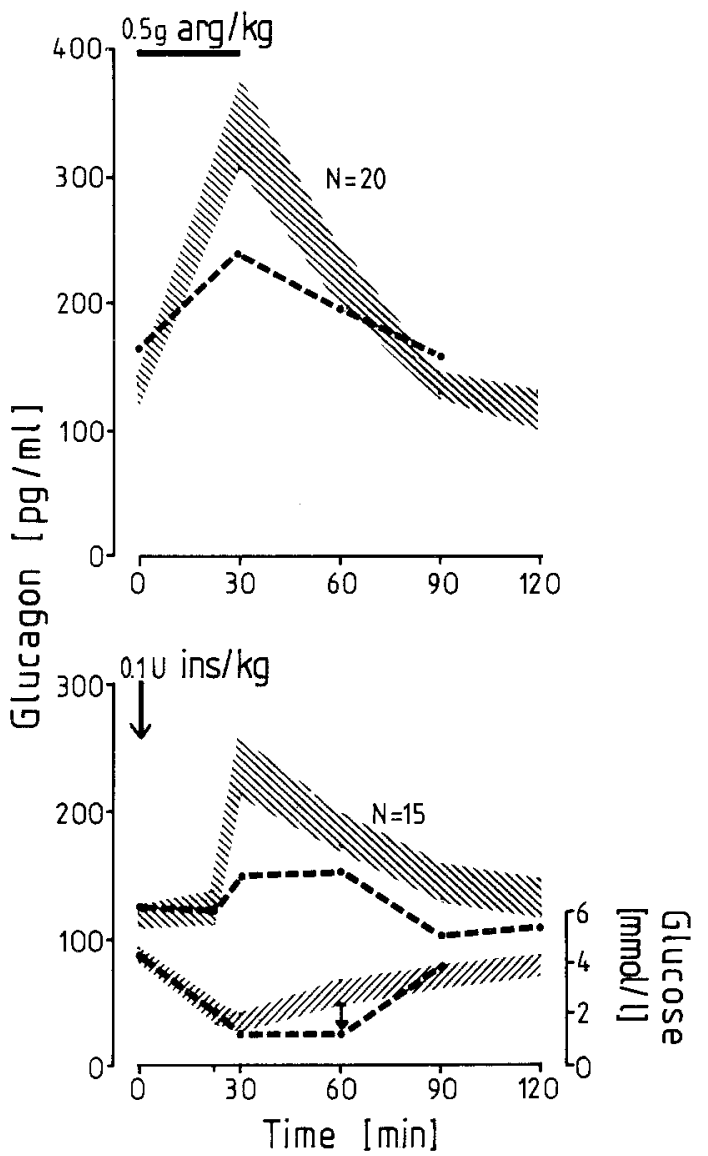

Fig. 1. Glucagon response to arginine $(0.5 \mathrm{~g} / \mathrm{kg}$ body weight; mean values of two tests on different days) and insulin-induced hypoglycaemia $(0.1 \mathrm{U} / \mathrm{kg}$ body weight, IV). The patient $(--)$ is compared with normal subjects (shaded area; mean \pm SEM). I indicates the onset of glucose infusion at clinical hypoglycaemia in the patient after insulin injection

ly with big plasma glucagon. ${ }^{125} \mathrm{I}$-insulin and ${ }^{125} \mathrm{I}$-glucagon were used as molecular weight markers. The recovery was $50-72 \%$ of total loaded IRG. Crystalline glucagon (Eli Lilly, Indianapolis, Indiana, USA) was loaded in control runs at two concentrations of 25 and $50 \mathrm{pg} / \mathrm{ml}(2.5 \mathrm{ml})$, eluting as IRG $\mathrm{I}^{3500} 84 \%$ and $94 \%$, respectively.

\section{Results}

\section{Laboratory Findings}

Routine clinical parameters were within the normal range including serum levels of vitamin $B_{12}$. Two hours after a $100 \mathrm{~g}$ oral glucose load, blood glucose rose to $8.0 \mathrm{mmol} / \mathrm{l}$ without late hypoglycaemia during the postabsorptive phase up to $5 \mathrm{~h}$. After a starvation period of $28 \mathrm{~h}$, she became clinically hypoglycaemic at a blood glucose level of $2.1 \mathrm{mmol} / 1$. At this time insulin levels were appropriately suppressed, excluding an insulinoma $(2.4-2.8 \mathrm{mU} / 1$ compared with $5.0 \mathrm{mU} / 1$ after an overnight fast).

Basal levels of thyroxine $\left(\mathrm{T}_{4}\right)$ were $3.6-4.3 \mu \mathrm{g} / \mathrm{dl}$ (normal $5.0-14.0 \mu \mathrm{g} / \mathrm{dl}$ ), 3-iodothyronine $\left(\mathrm{T}_{3}\right) 102$ $142 \mathrm{ng} / \mathrm{dl}$ (normal 60-200 ng/dl), and gastrin $5 \mathrm{pg} / \mathrm{ml}$
Table 1. Basal and peak glucose and hormone levels in the blood during the evaluation of the patient's endocrine status

\begin{tabular}{|c|c|c|c|c|}
\hline & $\begin{array}{l}\text { Insulin/ } \\
\text { LHRH/ } \\
\text { TRH- } \\
\text { injection }\end{array}$ & $\begin{array}{l}\text { Arginine } \\
\text { infusion }\end{array}$ & $\begin{array}{l}\text { ACTH } \\
\text { injection }\end{array}$ & $\begin{array}{l}\text { Vaso- } \\
\text { pressin } \\
\text { infusion }\end{array}$ \\
\hline \multirow[t]{2}{*}{ Time (min) } & 0 & 0 & 0 & 0 \\
\hline & 30 & 30 & 120 & 60 \\
\hline \multirow[t]{2}{*}{ Glucose (mmol/1) } & 4.5 & 4.8 & - & - \\
\hline & 1.4 & 5.3 & - & - \\
\hline \multirow[t]{2}{*}{ Glucagon $(\mathrm{pg} / \mathrm{ml})$} & 127 & 132195 & - & - \\
\hline & 153 & $215^{\mathrm{a}} 271^{\mathrm{b}}$ & - & - \\
\hline \multirow[t]{2}{*}{ Cortisol $(\mu \mathrm{g} / \mathrm{dl})$} & 0 & - & 00 & 0 \\
\hline & 0 & - & 2.01 .8 & 0 \\
\hline \multirow[t]{2}{*}{ ACTH $(\mathrm{pg} / \mathrm{ml})$} & - & - & & 37 \\
\hline & & & & 57 \\
\hline \multirow{2}{*}{$\begin{array}{l}\text { Growth hormone } \\
(\mathrm{ng} / \mathrm{ml})\end{array}$} & 1.0 & 1.0 & & \\
\hline & 2.0 & 1.0 & & \\
\hline \multirow[t]{2}{*}{ Prolactin (ng/ml) } & 23 & & & \\
\hline & 190 & & & \\
\hline \multirow[t]{2}{*}{$\mathrm{TSH}(\mu \mathrm{U} / \mathrm{ml})$} & 25.7 & & & \\
\hline & $>50.0$ & & & \\
\hline \multirow[t]{2}{*}{$\mathrm{LH}(\mathrm{mU} / \mathrm{ml})$} & 9.0 & & & \\
\hline & 33.5 & & & \\
\hline \multirow[t]{2}{*}{$\mathrm{FSH}(\mathrm{mU} / \mathrm{ml})$} & 5.5 & & & \\
\hline & 16.0 & & & \\
\hline
\end{tabular}

a $39 \%$ increase over basal value ${ }^{b} 63 \%$ increase over basal value

(normal $20-100 \mathrm{pg} / \mathrm{ml}$ ). Basal and peak hormone levels of standard endocrine tests are summarized in Table 1. Total IRG was within the normal range in the basal state [range $116-195 \mathrm{pg} / \mathrm{ml}$ on different days; normal range $60-200 \mathrm{pg} / \mathrm{ml}$, measured with $30 \mathrm{~K}$ antiserum, pool 5, lot 9, 1981]. Total IRG failed to increase appropriately during insulin-induced hypoglycaemia, and following an IV arginine load the IRG increase was $39 \%$ and $63 \%$ above basal levels on two different days compared with a $173 \%$ increase in normal subjects (Fig.1). Basal, post-insulin and post-arginine plasmas (drawn before development of diabetes) were chromatographed for glucagon assay. During basal conditions, levels of $I R G^{3500}$ were close to undetectable values $(1-3 \mathrm{pg} / \mathrm{ml})$ with a questionable increase to $18 \mathrm{pg} / \mathrm{ml}$ during insulin-induced hypoglycaemia. After arginine administration $\mathrm{IRG}^{3500}$ increased to $109 \mathrm{pg} / \mathrm{ml}$ and IRG ${ }^{9000}$ to $50 \mathrm{pg} / \mathrm{ml}$ (Fig. 2). In 18 normal subjects total IRG was $142 \pm 12 \mathrm{pg} / \mathrm{ml}, \mathrm{IRG}^{3500}$ amounting to $16 \pm 2 \mathrm{pg} / \mathrm{ml}$. In one normal subject IRG $\mathrm{I}^{3500}$ increased from 17 to $84 \mathrm{pg} / \mathrm{ml}$ during insulin-hypoglycaemia.

The titre of thyroid microsomal antibodies (Wellcome Thymune'M'Kit) varied from $1: 64,000$ to 1 : 102,000 during the 2.5-year period of observation and gastric parietal cell antibodies were constantly positive. Thyroglobulin antibodies (Wellcome Thymune'T'Kit) and antibodies to adrenal, pancreatic islet (either islet cell antibodies or specific glucagon or somatostatin cells), steroid and pituitary cells were constantly negative when tested by the indirect immunofluorescence technique using cryostat sections of the corresponding organs. The HLA determination was positive for HLA- 

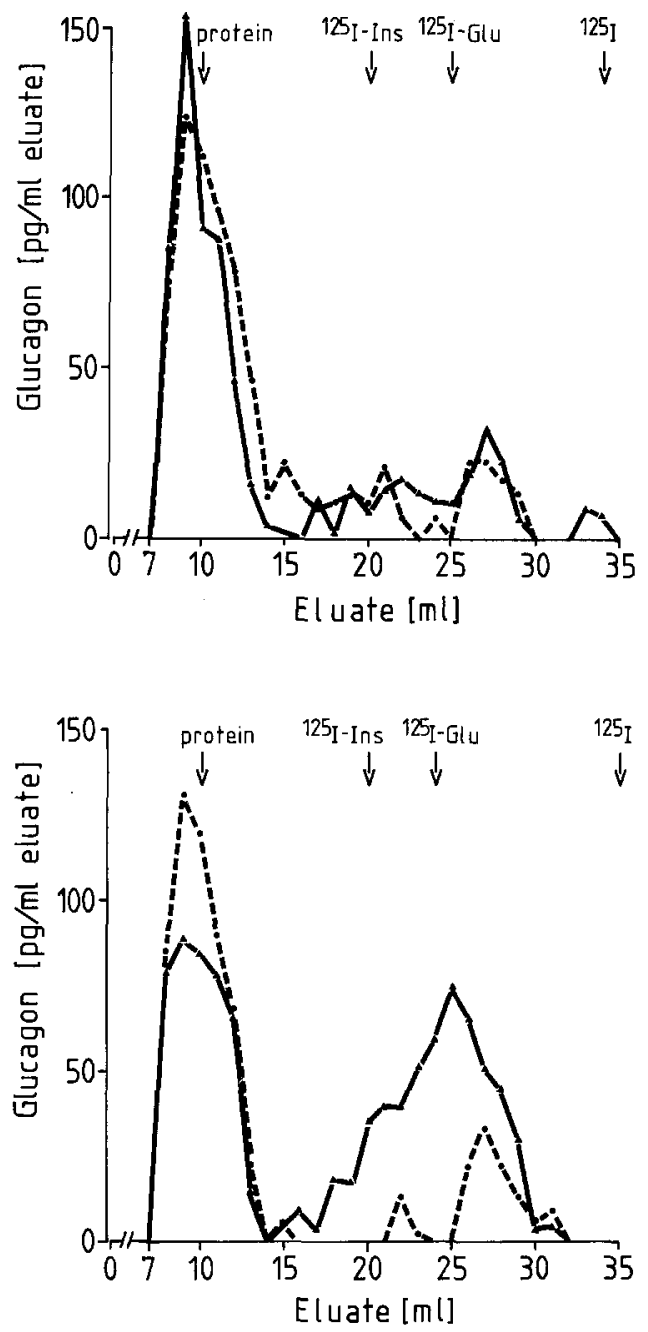

Fig. 2. Chromatographic elution patterns of the patient's plasma in the basal state $(---), 30 \mathrm{~min}$ after the insulin-induced hypoglycaemia (—, upper panel), and $30 \mathrm{~min}$ after arginine-stimulation of glucagon secretion (_ lower panel). The arrows indicate the elution volumes of the protein peak and the radioactive markers $\left(\mathrm{I}^{125}\right.$-Ins: ${ }^{125} \mathrm{I}$-insulin, ${ }^{125} \mathrm{I}$-Glu: ${ }^{125} \mathrm{I}$-glucagon, ${ }^{125} \mathrm{I}:{ }^{125} \mathrm{I}$-iodine)

B8, A1 and A3. The evaluation of serum amino acid levels after an overnight fast demonstrated moderate hyperaminoacidaemia; elevations of alanine $(532 \mu \mathrm{mol} / 1)$, glycine $(320 \mu \mathrm{mol} / 1)$, serine $(194 \mu \mathrm{mol} / 1)$, arginine $(142 \mu \mathrm{mol} / \mathrm{l})$ and ornithine $(110 \mu \mathrm{mol} / \mathrm{l})$ were detected, whereas the sum of branched chain amino acids (valine, leucine, isoleucine) was within the lower normal range $(377 \mu \mathrm{mol} / \mathrm{l})$. The patient was discharged on thyroid hormone and hydrocortisone replacement therapy. After 2 months she was admitted to another hospital after weight loss of $7 \mathrm{~kg}$ with ketoacidosis and hyperglycaemia of $25.0 \mathrm{mmol} / 1$ requiring constant insulin therapy. At that time, urinary C-peptide was $3.7 \mu \mathrm{g} /$ $24 \mathrm{~h}$ and plasma C-peptide level was $0.19 \mathrm{ng} / \mathrm{ml}$ in the basal state.

\section{Discussion}

The case of a female patient suffering from recurrent fasting hypoglycaemia associated with combined lack of glucagon, cortisol and growth hormone before the development of Type 1 diabetes is reported. Besides primary hypothyroidism, she presented with partial hypopituitarism (lack of growth hormone and ACTH response to adequate stimuli) and adrenal insufficiency. The presence of blunted cortisol secretion at normal or even low basal and non-stimulatable ACTH levels clearly revealed dysfunction of both the adrenal and pituitary glands. There was no deterioration of the gonadal axis. The presence of autoantibodies against the thyroid gland and gastric parietal cells as well as HLA-B8 indicates a polyglandular failure syndrome of autoimmune pathogenesis. The disparity between findings of hormone deficiencies and the presence of autoantibodies in this syndrome is well known [7]. However, it is striking that islet cell antibody testing was constantly negative before the manifestation of diabetes, although the pathogenesis of diabetes in this patient seems most likely to be of autoimmune origin. After two years of diabetes, ICA were still negative.

The fundamental contribution of glucagon to an appropriate glucose recovery from insulin-induced hypoglycaemia in normal subjects has been assessed during pharmacological glucagon deficiency by means of somatostatin infusions $[10,15]$. There is strong evidence that adrenaline secretion acts as a secondary defense against hypoglycaemia in the case of impaired glucagon secretion, whereas cortisol and growth hormone do not seem to be of critical importance in acute glucose counter-regulation. In this patient, in contrast to normal individuals, we observed insufficient, only marginal release of true pancreatic glucagon in the basal state and during severe insulin induced hypoglycaemia. Although adrenaline data are not available, it is apparent that the adrenomedullary system did not compensate for the impaired glucagon response. Thus, the question arises if the failure of glucose recovery was the consequence of a lesion in the central nervous system as outlined in a case report by Boden [16], or associated with the polyglandular failure syndrome as far as the adrenomedullary system is concerned. As thyroid hormone deficiency decreases the metabolism of various hormones (e.g., cortisol) without reducing production rates and cortisol deficiency is associated with increased glucagon levels [17], it seems unlikely that hypothyroidism and adrenal insufficiency accounted for the inappropriate glucagon response. Nevertheless, an increase of IRG ${ }^{3500}$ after intravenous arginine was clearly demonstrated by chromatography. The development of diabetes could not account for the impaired glucagon response to hypoglycaemia (plasma samples for chromatography were drawn before onset of diabetes) as it was shown recently that the impaired glucagon response to hypoglycaemia is acquired in Type I diabetic patients with duration of the disease [18].

The elevated serum levels of alanine, glycine, serine, arginine and ornithine were well in accordance with the deficiency of pancreatic glucagon as similar amino acid 
profiles have been shown in patients after pancreatectomy, when IRG ${ }^{3500}$ seemed to be completely or partially absent $[19,20]$. However, normal serum branched chain amino acids were in accordance with the normal insulin levels assayed before onset of diabetes.

In summary, we believe that the fasting hypoglycaemia and the failure of glucose recovery following insulin-induced hypoglycaemia already present in this patient before the onset of diabetes was primarily due to glucagon deficiency. Apparently, the adrenomedullary system did not compensate for the impaired glucagon secretion. Although islet cell antibodies were constantly undetectable despite the development of diabetes in our patient with the polyglandular failure syndrome, it is hypothesized that glucagon deficiency may sometimes be part of the syndrome.

Acknowledgments. The authors would like to thank Ms. G. Calvo for her skilled technical assistance. They acknowledge gratefully the cooperation of Drs. Herrmann, Hehrmann, Kley (Department of Medicine C, Düsseldorf University), Kolb (Diabetes Research Institute, Düsseldorf) and Bertrams (Elisabeth Hospital, Essen, FRG) with respect to the determination of various laboratory measurements. The study was supported in part by the German Research Association (SFB 113, funds made available to Dr. Starke).

\section{References}

1. Soloman N, Carpenter CCJ, Bennett JL, McGehee HA (1965) Schmidt's syndrome (thyroid and adrenal insufficiency) and coexistent diabetes mellitus. Diabetes 14: 300-304

2. Carpenter CCJ, Soloman N, Silverberg SG, Bledsoe T, Northcutt RC, Klinenberg JR, Bennett JL, McGehee HA (1964) Schmidt's syndrome: a review of the literature and a report of fifteen new cases including ten instances of coexistent diabetes mellitus. Medicine 43: 153-180

3. Sotsiou F, Bottazzo GF, Doniach D (1979) Immunofluorescence studies on autoantibodies to steroid-producing cells and to germline cells in endocrine disease and infertility. Clin Exp Immunol 39: 97-111

4. Doniach D, Bottazzo GF (1980) Polyendocrine autoimmunity. In: Franklin EC (ed) Clinical immunology update, Vol 2. Elsevier, New York, pp 95-121

5. Eisenbarth GS, Wilson PW, Ward F, Buckley C, Lebovitz H (1979) The polyglandular failure syndrome: Disease inheritance HLAtype and immune function. Ann Intern Med 91: 528-533

6. Goldstein GS, Drash A, Gibbs J (1979) Diabetes mellitus: The incidence of circulating antibodies against thyroid, gastric and adrenal tissue. J Pediatr 77: 304-306

7. Bottazzo GF, Pujol-Borrell R, Doniach D (1981) Humoral and cellular immunity in diabetes mellitus. Clin Immunol Allergy 1: 159

8. Vidnas J, Oyaseter S (1977) Glucagon deficiency causing severe neonatal hypoglycemia in a patient with normal insulin secretion. Pediatr Res 11: 943-949

9. Grollmann A, McCaleb WE, White FN (1964) Glucagon deficiency as a cause of hypoglycemia. Metabolism 13: 686-689

10. Rizza RA, Cryer PE, Gerich JE (1979) Role of glucagon, catecholamines and growth hormone in human glucose counterregulation. J Clin Invest 64: 62-71

11. Faloona GR, Unger RH (1974) Glucagon. In: Jaffe RB, Behrmann HR (eds) Methods of hormone radioimmunoassay. Academic Press, New York, pp 317-330

12. Felig P, Baxter JD, Broadus AE, Frohman LA (1981) Endocrinology and metabolism. McGraw Hill, New York

13. Berger $M$, Zimmermann-Telschow $H$, Berchthold $P$, Drost $H$, Müller WA, Gries FA, Zimmermann H (1978) Blood amino acid levels in patients with insulin excess (functioning insulinoma) and insulin deficiency (diabetic ketosis). Metabolism 27: 793-799

14. Valverde I, Dobbs R, Unger RH (1975) Heterogeneity of plasma glucagon immunoreactivity in normal, depancreatized and alloxan diabetic dogs. Metabolism 24: 1021-1028

15. Gerich J, Davis J, Lorenzi M, Rizza R, Bohannon N, Karam J, Lewis S, Kaplan R, Schultz T, Cryer P (1979) Hormonal mechanisms of recovery from insulin-induced hypoglycemia in man. Am J Physiol 236: E380-E385

16. Boden G, Reichard GA, Hoeldtke RD, Rezvani I, Owen OE (1981) Severe insulin-induced hypoglycemia associated with deficiencis in the release of counterregulatory hormones. $\mathrm{N}$ Engl $\mathbf{J}$ Med 305: 1200-1205

17. Bloom SR (1981) Control of glucagon secretion: An overview. In: Unger RH, Orci L (eds) Glucagon: physiology, pathophysiology and morphology of the pancreatic A-cell. Elsevier, New York, pp 99-113

18. Bolli $G$, DeFeo P, Compagnucci $P$, Cartechini MG, Angeletti G, Santeusanio F, Brunetti P, Gerich JE (1983) Abnormal glucose counterregulation in insulin-dependent diabetes mellitus. Interaction of anti-insulin antibodies and impaired glucagon and epinephrine secretion. Diabetes 32: 134-141

19. Boden G, Master W, Rezvani I, Palmer JP, Lobe TE, Owen OE (1980) Glucagon defíciency and hyperaminoacidemia after total pancreatectomy. J Clin Invest 65: 706-716

20. Müller WA, Berger M, Suter P, Cüppers HJ, Reiter WT, Berchtold P, Schmidt FA, Assal JP, Renold AE (1979) Glucagon immunoreactivities and amino acid profile in plasma of duodenopancreatectomized patients. J Clin Invest 63: 820-827

Received: 4 February 1982

and in revised form: 22 July 1983

Dr. A. A. R. Starke

Veterans Administration Medical Center

4500 South Lancaster Road

Dallas, Texas 75216

USA 